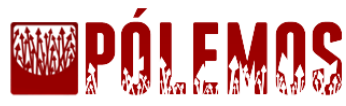

Contagem de palavras: 6959

\section{A construção do orador pelos Proêmios de Demóstenes}

\section{The Construction of the orator by Proems of Demosthenes}

\author{
Valesca Scarlat Carvalho da Fonseca \\ Universidade de Brasília, Brasil
}

\begin{abstract}
Demosthenes is known as an author of a corpus of isolated proems. If analyzed according to the three means of persuasion (éthos, páthos, lógos) of Aristotle's Rhetoric, these proems have metalinguistic character. They show an indirect manifestation of éthos when they build a more convenient image of the orator. Comparing the proems - which already develop the subject to be presented on the exposition and on the proofs of Demosthenes' complete discourses - the isolated ones present metalinguistic theme on how to make a proper deliberative speech. This paper intends to show that the isolated proems were probably written with no intentions of being used in future discourses. They can be the orator's practice in order to exercise his writing skills or arguments that build his character, as well as showing Demosthenes as a possible rhetoric theorist. This way, instead of contributing only with his discourses, Demosthenes may also have provided us with manuals of models that were typical of Ancient Athens.
\end{abstract}

Keywords: proem; deliberative speech; metalinguistic; êthos; rhetoric.

Resumo: Demóstenes é reconhecido como o autor de um corpus de proêmios isolados. Analisados de acordo com os três meios de persuasão do discurso (éthos, páthos, 
lógos), da Retórica aristotélica, os proêmios se apresentam com caráter marcadamente metalinguístico, em que se desenvolve o lógos argumentativo a respeito dos discursos deliberativos. Nota-se também uma manifestação indireta do ếthos, ao construírem a imagem do bom orador, que deve apresentar o melhor discurso. Comparados aos proêmios dos discursos inteiros de Demóstenes, os quais se desenvolvem em torno do assunto que será abordado na exposição e provas do discurso, os proêmios isolados apresentam majoritariamente o tema metalinguístico, tratando de como se fazer um discurso deliberativo. Neste artigo, pretendo mostrar que provavelmente tenham sido feitos sem a finalidade de serem utilizados em discursos futuros, podendo fazer parte de uma prática pessoal do orador, a fim de treinar sua habilidade escrita e argumentos que constroem o seu caráter, como também apresentar Demóstenes como um possível pensador da retórica, que pode ter contribuído, além de com seus discursos, com possíveis manuais de modelos, comuns em Atenas e reconhecidos como as primeiras contribuições à retórica.

Palavras-chave: proêmio; deliberativo; metalinguístico; ếthos; retórica.

Os eruditos da Biblioteca de Alexandria, durante o período helenístico, selecionaram os maiores oradores de Atenas que se destacavam pela sua capacidade oratória para compor o cânon dos dez oradores áticos. Estes, no geral, eram conhecidos por terem demonstrado grande eloquência enquanto apresentavam seus discursos nas assembleias, por exemplo, como foi o caso de Demóstenes, e pela capacidade discursiva, também expressa nos discursos que escreviam. Demóstenes, que era logógrafo, escrevia discursos para outros proferirem no tribunal, ou para ele próprio. Assim foi Demóstenes conhecido, em seu tempo e até os dias de hoje, como um grande orador que se utilizou da retórica para atuar na democracia ateniense. Dele nos chegou um corpus de proêmios isolados que talvez possa apresentar, além de uma prática pessoal do orador, a fim de treinar seus discursos, também uma reflexão ou preocupação com essa prática.

A democracia ateniense foi desenvolvida juntamente com a retórica, e esta foi 
definida por seus pensadores, ao longo dos séculos ${ }^{1}$. Pode-se dizer que a retórica é produto das mudanças econômicas efetuadas na política e na educação gregas (ou ateniense). Quando Draco, no meio do século VII (659-601 a.C.), governou e implementou as leis atenienses, ele estabeleceu uma nova forma de governar e, para que os cidadãos tivessem condições de participar ativamente das reuniões públicas da pólis, foi necessário que muitos se tornassem alfabetizados, pois o discurso estava relacionado ao poder da participação. Muitas mudanças sociais e econômicas também se iniciam no século VII a.C. Pequenos produtores que se deslocavam em busca de terras mais produtivas do que os acidentados e inadequados terrenos gregos, cansados de baixos rendimentos nas colheitas, no século V a.C. foram para as terras da Eubeia e Bósboro, mas, como precisavam de certo capital até que suas vinhas e pomares começassem a produzir, muitos desses pequenos produtores não tiveram outra alternativa a não ser irem para Atenas em busca de emprego. Outro fato social foi importante para que ocorressem mudanças na compreensão de mundo dos gregos, que foi o fato de que, no século V a.C., aproximadamente $30 \%$ da população de Atenas era de escravos. Toda essa mão de obra disponível para os trabalhos pesados permitiu que este passasse a ser visto como degradante, e a liberdade passa a ser ainda mais admirada. Com o Decreto de Sólon, foi autorizada a utilização de fundos públicos para comprar a liberdade desses atenienses, e essa revolução significou a oportunidade de estes, agora cidadãos livres, buscarem participação no processo político da pólis. Juntamente com essa nova concepção de liberdade, a guerra contribuiu para o desenvolvimento da retórica, quando os guerreiros retornaram da guerra do Peloponeso, inspirados pela democracia, desejando maior participação política, participação esta que exigia habilidade de oratória.

Os primeiros estudos formais de retórica na Grécia começaram em torno do ano 467 a.C. em Siracusa, na ilha da Sicília. Córax e Tísias são reconhecidos como os

\footnotetext{
${ }^{1}$ A definição de retórica atribuída a Córax e Tísias, Górgias e Platão: peithoûs dēmiourgós - $\pi \varepsilon 1 \theta 0 u ̃ \varsigma$ $\delta \eta \mu$ ¡ovpó́ (geradora de persuasão); a definição de Aristóteles: hē dè rhêtorikè perì toû dothéntos hōs

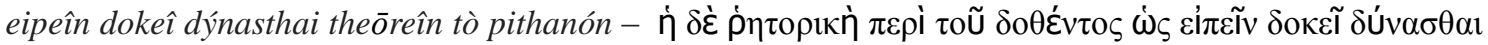

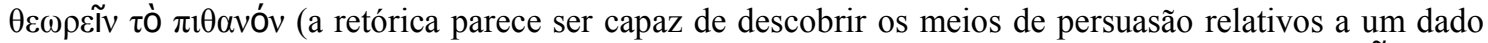

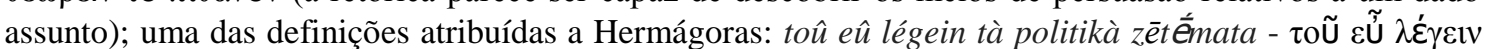

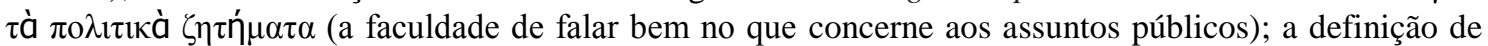
Quintiliano, na linha dos retóricos estóicos: scientia bene dicendi (a ciência de bem falar). Essas definições são citadas por Alexandre Júnior, M. Retórica. Aristóteles. Lisboa, Imprensa Nacional, Casa da Moeda, 2005, p. 22.
} 
precursores dessa prática de ensinar a retórica, assim como apresenta Aristóteles, na Arte Retórica. Mas a atenção pelo discurso sempre existiu na história da cultura grega, a admiração pela força e magia que ele possui. Neste contexto, Córax, observando os discursos forenses, percebeu certas técnicas que tornavam certos discursos mais bem recebidos que outros, e então desenvolveu um método para ensinar os cidadãos interessados. O material retórico utilizado eram os manuais, prática muito popular, principalmente em Atenas. Esses manuais possuíam discursos como modelos, compostos com técnicas retóricas, e serviam de exemplos e modelos para que os alunos pudessem observá-los e construírem seus discursos com base neles. M. Alexandre Júnior (2005, p. 19) observa que há evidências desses manuais que ofereciam técnicas para a arte de se falar bem em textos de Isócrates, Platão e Aristóteles:

Foi na Sicília que a retórica teve a sua origem como metalinguagem do discurso oratório. Por volta de 485 a.C., dois tiranos sicilianos, Gélon e Hierão, povoaram Siracusa e distribuíram terras pelos mercenários à custa de deportações, transferências de população e expropriações. Quando foram destronados por efeito de uma sublevação democrática, a reposição da ordem levou o povo à instauração de inúmeros processos que mobilizaram grandes júris populares e obrigaram os intervenientes a socorrerem-se das suas faculdades orais de comunicação. Tal necessidade rapidamente inspirou a criação de uma arte que pudesse ser ensinada nas escolas e habilitasse os cidadãos a defenderem as suas causas e lutarem pelos seus direitos. E foi assim que surgiram os primeiros professores da que mais tarde se viria a chamar retórica.

Neste contexto, Demóstenes é um completo produto do momento de Atenas. Seu pai faleceu quando ele tinha apenas sete anos, e o deixou em boas condições financeiras, porém seus tutores lhe roubaram uma parte da herança e da outra fizeram mau uso, de tal forma que ele não recebeu quando criança uma educação apropriada. Mas, admirado pelo poder dos discursos e daqueles que os declamavam, viu na retórica uma 
oportunidade de enriquecer, como muitos viram, ou simplesmente de recuperar seus bens. Tomou como seu mestre a Iseu, logógrafo especializado em casos de heranças, como demonstra sua obra, e também importante orador incluído no cânon dos dez oradores, fixado pelos eruditos da Biblioteca de Alexandria, segundo Plutarco. Plutarco também diz na sua Biografia que o historiador Hermipo encontrou evidências de que Demóstenes também frequentou a escola de Platão. Então, quando ele atingiu a idade permitida, processou seus tutores e ganhou a causa, não conseguindo reaver porém nenhuma parte de seu dinheiro, mas ganhou a fama para participar dos assuntos políticos, como bem exemplifica o trecho:

Quando Calístrato teve prosperidade e foi admirado maravilhosamente, pois ele buscou com louvor a sua fama, Demóstenes, vendo-o sendo acompanhado por todos e honrado, admirou-se principalmente com a palavra e refletiu sobre a sua força, que controla todas as coisas e que domestica naturalmente ${ }^{2}$.

Obviamente, Demóstenes não foi tão bem recebido em suas primeiras defesas, o que exigiu dele muito esforço e dedicação para adquirir habilidade, chegando até mesmo a treinar com um amigo ator de nome Sátiro a elocução, declamação, tom de voz e gestos para a eficácia do discurso. Seu esforço era tamanho que utilizava uma sala subterrânea todos os dias para o estudo e aperfeiçoamento, e, para não sair, raspava apenas uma parte da cabeça para ser obrigado a lá permanecer. Costumava também colocar pedras na boca e treinava a falar com elas, para melhorar a dicção. Como raramente se apresentava de improviso, pois preferia a preparação do discurso, Plutarco destaca (Dem., 8.3) que o seu grande esforço e preocupação em se preparar lhe concedeu a fama de não possuir habilidades naturais, e possuir a eloquência baseada apenas em trabalho de treino. Forte crítica, uma vez que a tradição da sociedade grega ainda era muito ancorada nas práticas orais, e com grande fascínio pelo improviso. A

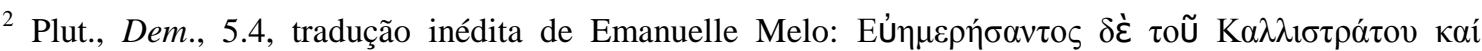

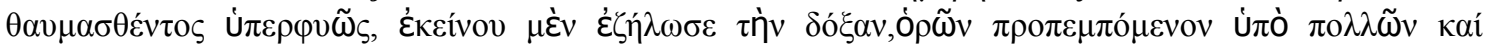

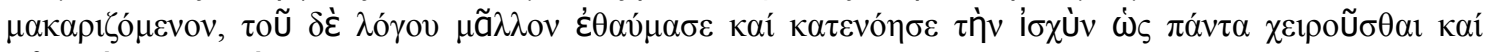

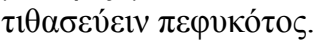


retórica ganhou mesmo seu espaço como uma arte a ser aprendida.

Ele teve uma opinião vinda disso a respeito de ser fraco, mas usava força e eloquência, que permaneciam juntas, originadas de seu trabalho. Parecia ser um grande indício disso, e ouvir algo quando Demóstenes falava em uma oportunidade foi difícil. Mas, também, quando ele estava sentado na assembleia, enquanto o povo o chamava pelo seu nome várias vezes, não falou em público, se ele não estivesse, por um acaso, preocupado e preparado ${ }^{3}$.

A educação dos meninos era ministrada por escravos, mas, no século V a.C., um grupo se ocupou de dar continuidade a esses estudos, os chamados sofistas. O mais conhecido sofista foi Górgias, natural da Sicília, que, também acreditando na expressividade da palavra, ganhou espaço na Ática, chegando até mesmo a incomodar os filósofos com sua "arte". Sua maior contribuição foi o espaço que a prosa dominou na retórica, uma preocupação com estilo e composição (Alexandre Júnior, 2005, p. 20). Eles ensinavam gramática e poesia, e foram construindo um vocabulário técnico que profissionalizasse a poesia, alterando sua forma de ser compreendida. Neste momento a prosa ganha espaço nos discursos políticos, e a poesia já passa a estar intimamente ligada a performances musicais.

Porém, com todo esse desenvolvimento da habilidade de se fazer discursos, aqueles que tivessem um discurso sem sucesso tinham a opção de encomendar este de uma pessoa com habilidades oratórias e conhecimento de retórica: o logógrafo, um escritor profissional de discursos jurídicos, como o foi Demóstenes. Essa foi uma prática que cresceu muito durante o século IV a.C., talvez por ter havido uma maior circulação de discursos a partir desse momento. Há até mesmo, se forem observados os estilos diferentes presentes em alguns discursos, evidências de trabalhos desenvolvidos



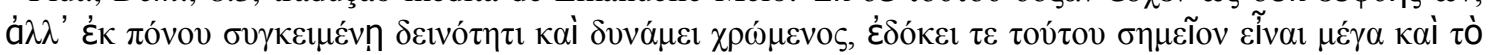

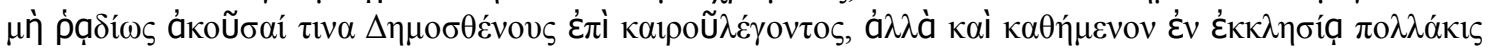

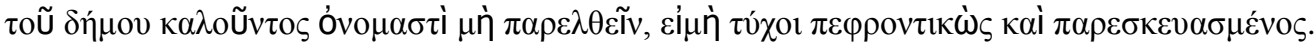


pelo logógrafo em parceria com o cliente ${ }^{4}$.

Já no século IV a.C., surge a mais reconhecida sistematização da retórica conhecida até os dias de hoje, a Arte Retórica, escrita por Aristóteles, aproximadamente entre 350 a.C. a 335 a.C. No livro I da Arte Retórica, Aristóteles apresenta os gêneros de discurso nos quais a retórica se manifesta: judicial, epidítico e deliberativo. $\mathrm{O}$ judicial ou forense, por ser utilizado para julgar, acusar ou defender atitudes já realizadas, aborda o passado, a fim de mostrar a justiça ou injustiça cometida. Os discursos epidíticos buscam elogiar ou censurar alguma qualidade ou pessoa, por isso abordam o presente. Também fazem parte destes os discursos fúnebres, pois visam a honrar pessoas, com o objetivo também educativo de instruir os ouvintes. Os discursos deliberativos, visando sempre o futuro, procuram tomar uma decisão sobre algo que acontecerá. Encontra-se uma grande evidência dessa importância do futuro no proêmio XX, em que Demóstenes defende que o passado só deve ser utilizado se for para melhorar o presente:

Se eu lembro de algo do passado (tốn pepragménōn - $\tau \tilde{\omega} v$ $\pi \varepsilon \pi \rho \alpha \gamma \mu \varepsilon ́ v \omega v)$, não considerai que eu falo no interesse de fazer acusação, mas para evitar de sofrer as mesmas coisas (hēmártete

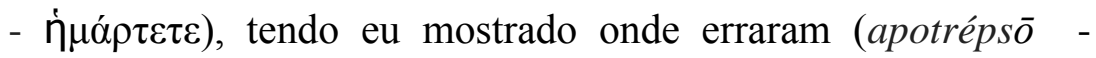
á $\pi 0 \tau \rho \varepsilon ́ \psi \omega)^{5}$.

Como é dito por Aristóteles (Rh. 1.4, 1359b), o orador deliberativo "se ocupa de coisas boas ou más, mas não de todas as coisas, apenas das que podem vir a acontecer ou não", ou seja, das que ele deva obter um certo controle. Na assembleia ou no tribunal de justiça, os principais assuntos desse tipo de retórica eram finanças, guerra e paz, defesa, importação e exportação e legislação $(1.4,1359 b 21-23)$. O objetivo final da deliberação é sempre trazer a felicidade para os seus componentes e, para isso, Aristóteles defende que é necessário conhecer todas as constituições, assim como seus costumes, instituições, para saber o que pode trazer benefício através de um bom conselho.

\footnotetext{
${ }^{4}$ Worthington, I. "Once more, the Client/Logographos Relationship". The Classical Quarterly, New Series, Vol. 43, no. 1, 1993, p. 67-72.

${ }^{5}$ Tradução de minha responsabilidade, a partir da consulta às traduções francesa, espanhola e inglesa.
} 
O livro III vai abordar o estilo e a composição do discurso. Sobre a linguagem a ser utilizada em cada gênero, o autor defende que, ao discurso demonstrativo, convém o estilo elevado; ao judicial, um estilo médio; e, ao deliberativo, convém um estilo natural, próximo da oralidade e da espontaneidade. Como ele deixa claro, as partes essenciais são a narração (exposição dos fatos) e a prova (demonstração dos argumentos levantados). As partes secundárias são o proêmio e o epílogo, que possuem em comum a característica de rememorar. O epílogo vai ampliar o assunto ao rememorar os argumentos principais da deliberação, será a conclusão que vai convencer aos ouvintes a serem favoráveis ao orador. O proêmio, por sua vez, será o início do discurso, onde os oradores buscam "acusar ou dissolver o que receiam". Conforme diz Aristóteles $(R h$. 1415d), "a função mais necessária e específica do proêmio é, por conseguinte, pôr em evidência qual a finalidade daquilo sobre que se desenvolve o discurso", e sua necessidade varia conforme a importância ou não do assunto de que se trata o discurso. Assim coloca Aristóteles:

Os proêmios do discurso deliberativo são baseados nos do gênero judiciário, sendo, no entanto, por natureza, de muito pouca importância. Efetivamente, o discurso deliberativo versa sobre algo de que o auditório tem conhecimento. $\mathrm{O}$ assunto não necessita de proêmio, a não ser que este respeite ao orador ou aos seus opositores, ou que se suspeite de que o assunto não é da importância que se quer dar, mas maior ou menor; por isso, é forçoso ou atacar ou refutar, amplificar ou minimizar o assunto. Nestes casos que é necessário um proêmio. Ou então, como motivo de ornamento, uma vez que, se não o tiver, o discurso poderá parecer feito à pressa $(R h .1416 a)$.

O adjetivo dēmégorikós apresenta a noção de "dirigido ao povo", que em retórica é um dos termos usados para designar os discursos na assembleia, os deliberativos, para distinguir estes dos judiciários e dos epidíticos. É atribuída a Demóstenes a autoria de um corpus de prooímia dēmēgoriká, 56 proêmios do gênero 
deliberativo $^{6}$. A autoria se baseia na proximidade das características formais do estilo retórico dos proêmios com trechos dos discursos inteiros do orador ${ }^{7}$, exibem as mesmas características de dicção, ritmo, pausa, ordem das palavras, estrutura das frases que marcam o estilo de Demóstenes, e que bem o diferem de outros oradores ${ }^{8}$. Alguns pesquisadores desacreditam essa tese ao levantar o fato de existirem fórmulas na oratória ática, que frequentemente poderiam ser copiadas por outros autores, fato que obviamente ocorria, mas as semelhanças vão além. Outra prova a favor da autoria demostênica é o tema dos proêmios e dos discursos do orador, ou seja, em conteúdo, grande parte trata da degradação que a política ateniense estava sofrendo a partir do século IV a.C., representando a inconformidade do orador a respeito dos interesses comuns do povo. Há evidências de que outros autores de retórica do período clássico, como Antifonte, Trasímaco e Crítias, também compuseram um corpus de proêmios isolados semelhante ao de Demóstenes, segundo Cole (1995, p. 256).

Well before Demosthenes' time it was possible to parody rhetorical preambles, which suggests a general awareness of diction that was standard of preambles. And I discussed above the theory of the rhetorical preamble from which Plato borrowed when in the mid fourth century he conceived his new genre of legal preambles (VIII.3, esp. n. 23). All this evidence suggests that Demosthenes' close attention to preambles fits easily into the intellectual milieu of fourth-century Athens.

\footnotetext{
${ }^{6}$ Antonio López, o tradutor da versão espanhola dos proêmios explica a numeração destes na nota 1 , $\mathrm{p}$. 337: "Bekeler, en su edición de 1824, distinguió cincuenta y seis prólogos. Otra numeración sigue R. Clavaud (Démosthène, Prologues, Paris, Les Belles Lettres, 1974), para quien los prólogos III e IV de Bekeler constituyen una unidad".

7 "Il faut partir d'un archétype unique où se trouvaient déjà un certain nombre de fautes communes à tous nos manuscrits. Les prologues n'y étaient pas toujours distingués les uns des autres d'une manière très claire. On le situera avant le $\mathrm{II}^{2}$ siècle de notre ère, car le papyrus a des leçons qui supposent déjà une contamination des trois familles, avec une prédominance des leçons de la troisième; cette conclusion est en partie confirmée par Harpocration qui attribue ó $\rho \omega \delta \varepsilon \tilde{I} v$ aux prologues de Démosthène; or, ce mot qui figure dans le prologue 52 (53), est donné par YDrWb, autrement dit par la deuxième et la troisième famille (la vraie leçon á $\rho \omega \sigma \tau i ́ \alpha$ est donnée par $S W^{a} F Q$ ): vu lá séparation de $\mathrm{r}$ et $\mathrm{W}^{\mathrm{a}}$ pour ce mot-là, on est autorisé à conclure que $\mathrm{A}$, dont ils descendent, portait les deux leçons, l'une dans le texte, l'autre comme variante, et que $\mathrm{r}$ et $\mathrm{W}^{\mathrm{a}}$ se sont séparés sur le choix de l'une ou l'autre leçon. Il n'est pas indifférent de remarquer que le papyrus présente des variantes de ce type-là dans l'interligne" (Clavaud, 1974, p. 81).

${ }^{8}$ Cole, T. The Origins of Rhetoric in Ancient Greece. Baltimore and London, The Johns Hopkins University Press, 1995, p. 118.
} 
Alguns dos proêmios são fragmentos de outros discursos inteiros do autor. Como no corpus de proêmios isolados não há uma cronologia, a única forma de situá-los temporalmente é observando ideias comuns que também se realizam nos discursos inteiros. Esses proêmios que são trechos dos próprios discursos, quatro no total, também podem de certa forma delimitar um tempo mais provável para a produção desses proêmios. O discurso "Sobre as Simorias" é datado de 354 a.C., o mais antigo deles a apresentar um proêmio que também está nesse corpus de proêmios isolados. Depois seguem o proêmio de "Em defesa dos megalopolitas", de 353 a.C., o de "Pela liberdade dos Ródios", de 350 a.C., e o proêmio de "Olintíaco I", de 349 a.C. Pode-se então suspeitar-se de que, nesse período de cinco anos, que foi de 354 a 349 a.C., possam ter sido produzidos esses proêmios, ou parte deles ${ }^{9}$.

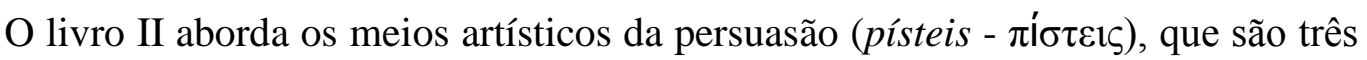
meios de prova, ou modos de apelo. O lógos vem a ser os meios derivados dos argumentos verdadeiros ou prováveis, que constroem a lógica do assunto. O páthos é a emoção que o orador pode vir a despertar nos ouvintes, e o éthos são os meios derivados do caráter do orador, a fim de causar certa comoção do público em relação a este. É interessante observar que o éthos apresentado por Aristóteles é construído apenas no momento em que o orador está se apresentando, ou seja, toda a imagem do caráter do orador se faz durante a sua performance na assembleia, como se ele fosse uma figura desconhecida, não levando em consideração o histórico pessoal já reconhecido do retor. Outra sistematização retórica, a Retórica a Alexandre, de pseudo-

\footnotetext{
${ }^{9}$ Por la idea defendida y el tono adoptado por el orador, el prólogo L parece también ser de la misma época que el discurso Sobre las Sinmorías. El prólogo número VIII, que casi es idéntico al de la pieza titulada En defensa de los megalopolitas, debe datar, como este mismo discurso, del año 353 a.C. En el prólogo XXI y em el Contra Filipo, primer discurso, Demóstenes alude a la incursión de Filipo em Maratón (cf. Demóstenes, Contra Filipo, I 34), por consiguiente, pueden ser fechados ambos, tanto el referido proemio, como el discurso, em el 352 a.C. El prólogo XXXVII tiene concomitancias temáticas y formales com el discurso que lleva por título Por la liberdad de los rodios, del 351 a.C. En el prólogo em cuestión, efectivamente, se refería también el orador a los de Quíos y Rodas, sufrían por obra de Mausolo. Por razones similares habría qua tribuir la misma fecha a los prólogos XXII y XXIV. El prólogo IV coincide práticamente com el del Olintíaco I; el XV es fruto de la combinación de pasajes de los Olintíacos primero y tercero; el XXIII contiene párrafos que em forma muy semejante figuran em el Olintíaco I y en el Contra Filipo, primer discurso; el prólogo LIII se halla muy cerca, em expresión y contenido, de algunos pasajes del Olintíaco III; el XXX y el XLI hay que ponerlos em conexión, necesariamente, com los Olintíacos: el último de éstos, em concreto, reproduce al pie de la letra un lugar del Olintíaco I, aquél em que se refieren las pérdidas sufridas por Atenas (cf. Demóstenes, Olintíaco, I 10); al XXXIX hay que situarlo cronológicamente al día siguiente de la batalla de Queronea. (A. López, Demóstenes. Discursos Políticos III, p.338).
} 
Aristóteles, já faz uma clara distinção em relação ao êthos, de forma que para ele este não necessita ser totalmente desconhecido, pois é possível ao orador utilizar-se de sua credibilidade e experiência em certos assuntos, para que ganhe maior confiança de seu público $^{10}$.

Analisando o corpus de proêmios separados de discursos políticos de Demóstenes a partir destes três modos de apelo, pode-se notar a predominância do êthos sobre os outros meios, a fim de construir o caráter do orador. Como já afirma a Retórica, (1377d), "a forma como o orador se apresenta é mais útil nos atos deliberativos", desta forma, prática notável nos proêmios. A construção desse êthos se desenvolve de forma interessante: predomina como assunto principal dos proêmios uma linguagem metalinguística, em que se desenvolve o lógos argumentativo em torno deste centro. Demóstenes explica em muitos deles o poder da oratória, das intenções dos oradores, da importância de se estar persuadido, da importância do papel do ouvinte no ciclo da oratória; afinal, é este quem irá julgar e decidir qual o argumento que será colocado em prática (e não o orador, somente com a retórica), como devem se portar os ouvintes, dentre outros assuntos que tratam do discurso retórico e da relação deste com o seu público. Demóstenes se utiliza de um discurso metalinguístico nos proêmios, de forma que na grande maioria destes ele está apresentando a necessidade de seu discurso, se mostrando compreensível com a necessidade dos ouvintes, preocupado com a recepção deste, até mesmo em relação ao tempo do discurso, pois defende a noção de discurso 'direta, breve e conveniente', como pode-se ver no proêmio IV:

$\mathrm{Eu}$, portanto, não tenho o costume de falar por longos discursos (makrologeîn - $\mu \alpha \kappa \rho о \lambda о \gamma \varepsilon \tilde{v})$, e nem teria feito o uso disso agora se o tivesse; por outro lado, o que reconheço lhes ser útil

\footnotetext{
10 "Authority seems to have its origin in two different things: within 'discourse' and in that case it is the outcome of speech itself, and in an external origin (good repute). This, at least, is what can be understood from a sentence like the following: "You should bring out your own practical experience on the subjects treated and show that it is your interest to tell the truth about them" (1431b10-12). Here, practical experience partly relates to the self-image the orator has formed in the course of his life, as could already be guessed from the meaning of the word doxa, referring to opinion and reputation at the same time. And furthermore, the refutation will consist in saying that 'quite often, even experienced men may make mistakes' (15-16). However, this experience should also be manifested in and through discourse itself ('bring out', 'show') whereas in Aristotle, ethos is only discursive, hence its classification among the technical means of persuasion (Rhet. 1.2 1356a1-2)" (Chiron, P. "The Rhetoric to Alexander", em Worthington, I., A Companion to Greek Rhetoric. Oxford, Blackwell, 2010 p. 95)
} 
(symphérein - $\sigma 0 \mu \varphi \varepsilon ́ \rho \varepsilon \imath v)$, isto eu direi a vocês do modo mais breve que eu for capaz (brakhytátōn - $\beta \rho \alpha \chi u \tau \alpha ́ \tau \omega v) " 11$.

O proêmio de número $X$, de certa forma, apresenta a retórica e sua existência enquanto há a necessidade de tomar decisões, e que esta se cumpre através do ouvinte, que escuta o orador, analisa-o, e pratica seus conselhos quando são favoráveis. Todo o lógos do texto é utilizado para apresentar o ato deliberativo em si, a forma como um discurso e seus ouvintes devem proceder. Demóstenes diz, neste proêmio, que é um erro aconselhar àqueles que não analisam os conselhos dos oradores, e expõe que o público pode descobrir quem são os melhores conselheiros ao analisarem as sugestões destes. Chega a dizer que, se o povo não ouvir os seus opositores (tốn antilegóntōn - $\tau \tilde{\omega} v$

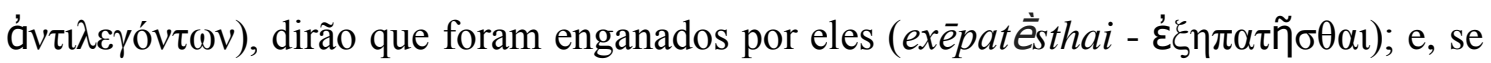
escutarem e não forem persuadidos ( $m \dot{\bar{e}}$ peisthếte - $\mu \grave{\eta} \pi \varepsilon 1 \sigma \theta \tilde{\eta} \tau \varepsilon)$, verão que eram maus

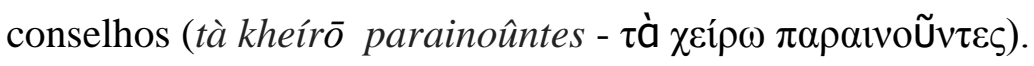

Porém nota-se com maior frequência uma manifestação indireta do éthos, que se constitui da seguinte forma.

O orador primeiramente constrói o êthos dos oradores em geral, enfatizando a importância destes para a ordem política da cidade, e a necessidade de seus discursos, para que os cidadãos possam, ouvindo todos, decidir se há algum melhor, ou mesmo se nenhum orador foi capaz de persuadir ao público de que seus argumentos são melhores. Para que o cidadão possa continuar com a sua posição, e colocá-la em prática sem dúvida de estar agindo de forma errônea, é preciso ouvir e analisar a todos os discursos, para poder concluir que não há nenhum melhor do que o de determinado orador. Desta forma, Demóstenes apresenta o trabalho dos oradores, sua função de ser persuasivo, as responsabilidades para com os ouvintes e com o melhor e conveniente para a pólis. Assim, criando o perfil dos bons oradores, com certa competitividade, ele intenta fazer com que o público seja capaz de reconhecer o melhor orador, mas, de certa forma, ele já é o destacado entre todos os outros.

No proêmio XXXII. 1, Demóstenes critica muitos dos oradores dizendo que a maior parte deles se importa mais em parecer eloquente e hábil (hópōs tà béltist' eroûsin

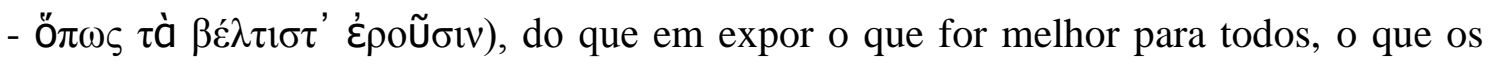

\footnotetext{
${ }^{11}$ Tradução de minha responsabilidade, a partir da consulta às traduções francesa, espanhola e inglesa.
} 
faria possuir uma fama melhor, a de homens decentes ${ }^{12}$.

No trecho 2 do proêmio XXXVI, Demóstenes apresenta fortes críticas aos outros oradores, dizendo que não considera prudente gastar tempo iludindo o público, e por isso ele se difere por apresentar um discurso que pode ser analisado e considerado conveniente. Demóstenes chega a dizer, alegando que não quer provocar esses maus

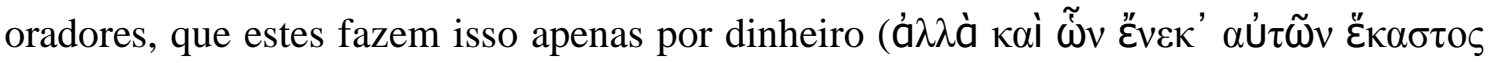

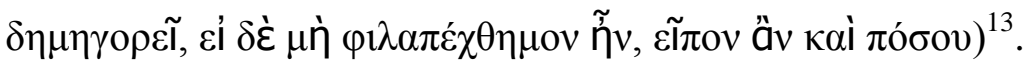

Há também um apelo excessivo de Demóstenes para que os ouvintes analisem sempre todos os discursos, chegando até mesmo, de forma pedagógica, a explicar como os ouvintes devem analisar e como devem exigir que os oradores se comportem. Um dos conselhos é não permitir que os oradores abordem outros assuntos que não sejam os que o público já vem ouvindo e analisando. Outro é instruir o público de que devem

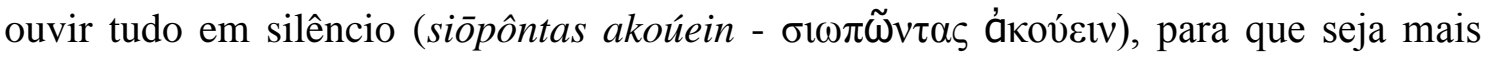
fácil o julgamento do melhor conselho (kai pótera dikaióter'àn proéloith'hē pólis - кaì

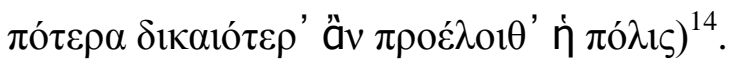

A partir do momento em que o público for capaz de julgar os melhores discursos, poderão notar também quais são os melhores oradores, e neste ponto é onde Demóstenes faz a sua crítica aos outros companheiros de ofício, relatando quais são as piores atitudes dos oradores, como um bom e um mau orador devem se portar, e é desta forma que se pode notar a manifestação indireta do éthos: através da crítica a outros

\footnotetext{
12 XXXII. 1: "Quisesse, varões atenienses, que alguns dos oradores pusessem o mesmo empenho em expor os melhores conselhos que em passar por eloquentes, para que eles fossem considerados homens decentes, em vez de tribunos hábeis no uso da palavra e seus assuntos, como conveniente se achassem em melhor situação. Mas a realidade é que alguns me parecem que estão de todo contentes com a reputação que lhes vêm da oratória e não se preocupam em absoluto do que logo ocorrerá a vocês (...)" (tradução de minha responsabilidade, a partir da consulta às traduções francesa, espanhola e inglesa).

${ }^{13}$ XXXVI. 2: "Em segundo termo, vocês não apenas conhecem de antemão os discursos que cada orador poderia dirigir a vocês, mas também, por que razão cada um deles dirige sua alocução ao povo, e se não fosse uma provocação, diria que por dinheiro o fazem. Por conseguinte, a mim ao menos parece que são prudentes reduzir ao mínimo o tempo dedicado a ser iludidos. Pois se eu me importasse em dizer o mesmo que os demais, não acreditaria em mim no dever de importunar vocês ao falar; mas tal como estão as coisas, creio que vou pronunciar um discurso que a vocês convém escutar e que está totalmente apartado do que espera a maioria; será breve o discurso em questão; escute, examine e se os agrada, o adote (...)" (tradução de minha responsabilidade, a partir da consulta às traduções francesa, espanhola e inglesa).

${ }^{14}$ LVI. 3: "Em primeiro termo, varões atenienses, que reclamem ao que se chegue à tribuna para falar sobre as questões que vocês estão examinando. Porque muitos outros assuntos poderiam incluir em um discurso e expressar sobre tudo, tal como fazem alguns desses indivíduos que são hábeis em seu ofício. (...) A segunda (que a alguns talvez vá aparecer chocante, diz respeito ao feito de que os discursos sejam mais breves) é que vocês escutem em silêncio" (tradução de minha responsabilidade, a partir da consulta às traduções francesa, espanhola e inglesa).
} 
oradores, realçando seus defeitos e incapacidades, ou exaltando as qualidades que todo bom orador deve possuir, ele constrói a imagem dos bons oradores, nos quais ele se insere, pois ao mesmo tempo ele afirma não fazer parte destes maus oradores, e, consequentemente, as características que ele exalta são as suas próprias características. Indiretamente, Demóstenes apresenta tudo o que possui um mau orador e, se diferenciando destes, "afirma" indiretamente ser superior a todos eles.

É notável como esta ênfase serve para convencer o público da importância do discurso e do papel do orador, enquanto também fala de como é composto um discurso e das intenções deste, e do papel do público em como deve reagir ao discurso.

Demóstenes é tão enfático em construir seu caráter de bom orador através de conselhos prudentes, que apresenta no proêmio XIII características autobiográficas, como o fato já apresentado de o orador ter conquistado seu espaço com sacrifício e ser mal visto no início de sua carreira; isso representa o foco do éthos que este orador constrói neste corpus. Ele pede para que o povo analise os conselhos que lhe são oferecidos, e não a pessoa do orador (ei mè tón légonta, allà tà symbouleuómena

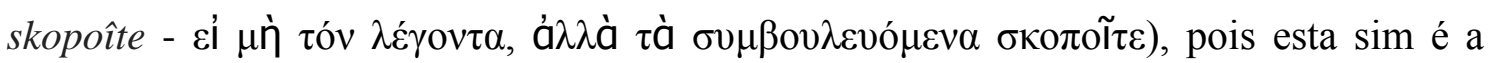
obrigação do bom orador ${ }^{15}$.

Seria possível, talvez, compreender então o fato de Aristóteles não apresentar o éthos relacionado à figura e conhecimento que se tem do orador, pois poderia ele também considerar que os argumentos, sendo a verdadeira parte a ser analisada, poderiam resgatar aos ouvintes o caráter do orador. Através da análise de seu lógos, poder-se-ia conhecer de melhor forma o éthos do orador, mais do que ouvindo a opinião pública.

O páthos está presente mais como uma forma de aproximação e cumplicidade do orador para com seus ouvintes, compartilhando os mesmos pontos de vista, a fim de cativá-los ao se mostrar próximo, mas essa aproximação não é tão recorrente nos proêmios como a construção do éthos, que se apresenta na grande maioria. Um exemplo

\footnotetext{
${ }^{15}$ XIII. 1b: "Não obstante, eu estou preocupado, tão seguro de que os oferecerei conselhos mais convenientes que os desses indivíduos, que não vacilarei em afirmar que tudo o que tenham podido dizer não tem valor algum. Considero que também agiriam com acerto se vocês examinassem não a pessoa do orador, mas os conselhos que eles oferecem a vocês. Porque essa é a obrigação, varões atenienses, que com sua benevolência contam não alguns, como se de um privilégio hereditário se tratasse, mas aqueles que em cada ocasião os fazem com seus discursos as melhores recomendações" (tradução de minha responsabilidade, a partir da consulta às traduções francesa, espanhola e inglesa).
} 
é o trecho do proêmio II bis, em que Demóstenes diz que a situação atual não está agradável para eles (incluindo ele, o orador), e nem para os aliados destes (reconhecendo serem seus aliados também os aliados de seu povo), e se iguala a todos

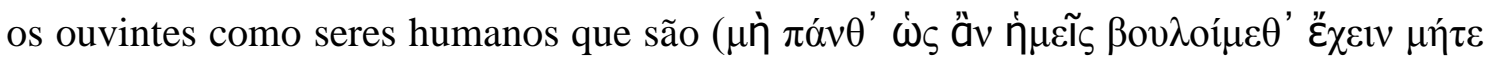

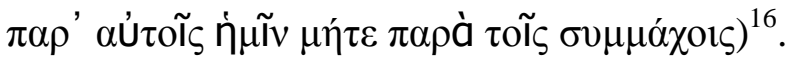

De forma interessante, Alfred P. Dorjahn ${ }^{17}$ defende fórmulas criadas por Demóstenes, utilizadas em alguns discursos e nos proêmios, para criar um ambiente de “improvisação". Como diz a literatura, o orador não se apresentava de improviso, então, seria lógico pensar que as passagens aparentemente "improvisadas" presentes na sua obra sejam mesmo nada mais do que suas próprias fórmulas, pois são aparentemente insignificantes e um tanto inerentes ao discurso, parecem ser estereotipadas e com padrões estabelecidos. É incoerente pensar que uma frase, que aparenta ser pensada na hora, apareça em outros discursos com a mesma naturalidade. Essa improvisação poderia transmitir confiança aos ouvintes, e também ser uma forma de construir o êthos, como Dorjahn afirma (1957, p. 292):

A good logograph, therefore, had to create the impression that his client was delivering a speech of his own making. Perhaps what the Greeks called êthos was the most effective device in achieving this end, but an atmosphere of improvisation was by no means a negligible factor.

Para ele, as referências a autores que se apresentam antes de Demóstenes, como ele coloca, "imaginários", e essa oposição criada pelo orador aos outros oradores, são estratégias pré-formuladas com o intuito de apresentar um discurso mais descontraído, que aparente ser improvisado. Os proêmios isolados poderiam, então, ser uma prática pessoal de treinamento do orador, a fim de melhorar suas habilidades e treinar argumentos e estratégias que seriam incorporadas em seus discursos inteiros, como

\footnotetext{
${ }^{16}$ II bis: “Agora, bem, varões atenienses, apesar de que tudo não esteja como queríamos, nem entre nós, nem entre nossos aliados talvez nada tenha de estranho; pois em muitos acontecimentos domina a espontaneidade da sorte e muitos são os pretextos para que não resulte tudo segundo nossos planos, sendo como somos, seres humanos" (tradução de minha responsabilidade, a partir da consulta às traduções francesa, espanhola e inglesa).

${ }^{17}$ Dorjahn, A.P. "Extemporaneous Elements in Certain Orations and the Prooemia of Demosthenes". The American Journal of Philology, Vol. 78, n 3, 1957, p. 287-296.
} 
certas orações que pretendiam fazer com que o discurso aparentasse ser um tanto improvisado.

Uma consideração importante é feita por J. F. Dobson e A. Mahoney ${ }^{18}$, a respeito do trabalho do orador Lísias, sobre o qual eles observam:

It is remarked by Dionysius that, though he (Lysias) composed two hundred speeches, he never used the same preface twice. Some orators were in the habit of using over again the opening sentences which had already served as introduction to an old speech, and even borrowing such proems whole from the speeches of their predecessors or from rhetorical handbooks.

Observando o trabalho de Lísias, esses autores apresentam uma provável prática recorrente naquele tempo, que era a de copiar frases ou até trechos inteiros de proêmios e discursos presentes nos manuais de retórica. Demóstenes pode ter sido um desses autores a contribuir com um manual de exemplos, manual que não tenha divulgado e por isso não aparece "citado" em discursos de outros oradores, mas tenha feito uso ele próprio, reutilizando alguns de seus proêmios em discursos inteiros.

No entanto, esta característica de proêmio metalinguístico ocorre com mais frequência nos proêmios que foram encontrados isolados, e ocorre de forma menos desenvolvida ou até mesmo ausente nos proêmios dos discursos inteiros, e dos discursos do gênero judiciário.

No discurso "Contra Leptines", percebe-se que este, desde o início, se desenvolve em torno do assunto principal para qual será dissertado. O proêmio deste discurso, se for possível assim considerar, se estende até o primeiro ponto final, pois a partir deste, os argumentos do discurso já estão sendo desenvolvidos. Ele apenas

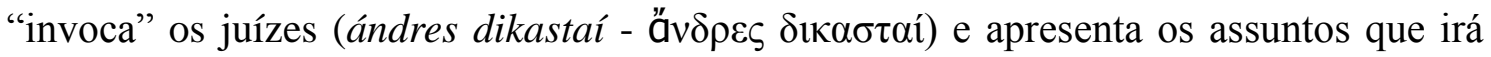

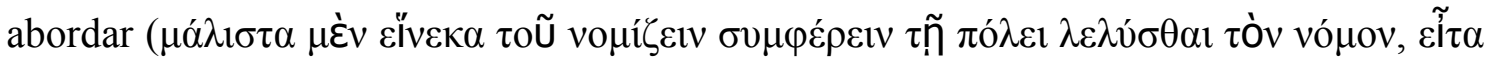

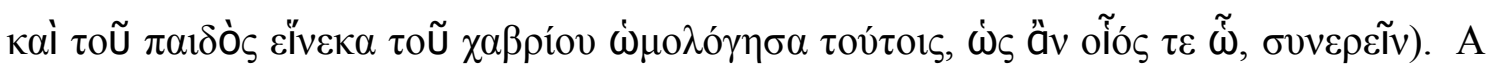

\footnotetext{
${ }^{18}$ Dobson, J. F. e Mahoney, A. The Greek Orators, "Lysias". Londres, Methuen and Co., 1919, seção 4. 3. Disponível section\%3D3. Acesso em 27 abril 2012.
} 
diferença de assuntos entre este e os proêmios isolados é notável e óbvia.

É interessante observar a diferença do vocativo do discurso deliberativo e do discurso jurídico, que demonstra a diferença prática entre esses gêneros. Enquanto o discurso deliberativo é apresentado para a assembleia, Demóstenes utiliza como

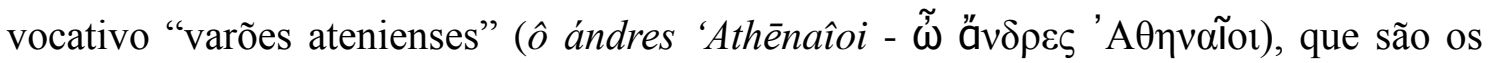
cidadãos atenienses que participavam das sessões deliberativas. Já o vocativo presente

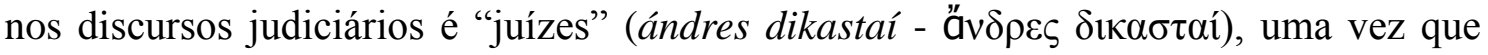
eram analisados por juízes a julgar as causas apresentadas.

Em relação aos três meios de persuasão que predominam nos proêmios destes discursos completos, se sobrepõe o lógos, que desenvolve argumentos já ligados aos temas dos discursos. Em alguns destes, o proêmio se apresenta muito pequeno e pouco desenvolvido, e outros discursos nem mesmo os têm. Como na Arte Retórica afirma Aristóteles (1415b), "os proêmios do discurso deliberativo são baseados nos do gênero judiciário, sendo no entanto, por natureza, de muito pouca importância”, uma vez que o assunto dos discursos deliberativos já são de conhecimento dos ouvintes, então, o proêmio pode ser ilustrativo, abordando outros temas.

Os proêmios isolados de Demóstenes, como proêmios de discursos deliberativos, apresentam essa característica de não apresentar o tema que será desenvolvido no discurso, uma vez que ilustram com um discurso metalinguístico, como diz Dorjahn (1957), para criar uma áurea improvisada no discurso, ou, como defendo, para construir seu éthos como um orador diferenciado e melhor do que os outros, pois, nos deliberativos, em geral já no tempo desses oradores, é mais comum o orador ter falado emitindo sua própria opinião, ou seja, os deliberativos tendem a refletir a inserção do próprio sujeito no contexto político. Diante da assembleia, ele se apresenta e se expõe, dando opinião, sendo, então, necessário construir um éthos confiável e superior para ser digno de ser ouvido e analisado. Os discursos judiciários e epidíticos, na maioria das vezes, no caso do logógrafo, são discursos encomendados.

Isso leva a pensar que, já que os proêmios dos discursos inteiros já se desenvolvem em torno do assunto que será abordado na exposição e provas do discurso, e os proêmios isolados apresentam majoritariamente o tema metalinguístico, estes últimos podem não ter sido feitos com a finalidade de serem utilizados em discursos futuros. Mas podem, conforme Dorjahn (1957), terem servido também como modelos 
para que o orador pudesse utilizá-los em momentos de apresentação improvisada, que não seria tão improvisada, pois ele teria elaborado esses modelos previamente, e poderia tê-los memorado para esses momentos. Podiam também fazer parte de uma prática pessoal do orador, a fim de treinar sua habilidade escrita e argumentos que constroem o seu caráter, uma vez que se sabe como Demóstenes se esforçou para aprender e dominar a retórica. Pode-se pensar ainda que possam ter sido reunidos para compor um possível manual, se não reunidos pelo próprio Demóstenes, por algum estudioso de retórica. 